\title{
WORKING CAPITAL EFFICIENCY TOWARDS PROFITABILITY IN THE SAMI JAYA CREDIT COOPERATIVE IN KUPANG
}

\author{
Marince A. Rata ${ }^{1}$, Paulina Y. Amtiran ${ }^{2}$ \\ 1,2 Universitas Nusa Cendana,marincerata66093@gmail.com; paulinaamtiran@staf.undana.ac.id
}

\begin{abstract}
ABSTRAK
Penelitian ini bertujuan untuk mengetahui modal kerja yang sudah dikelola secara efisien, untuk mengetahui pengaruh modal kerja terhadap profitabilitas dan untuk mengetahui faktor-faktor yang mempengaruhi efisiensi modal kerja pada Koperasi Kredit Sami Jaya Kupang. Periode penelitian yang digunakan adalah periode tahun 2015 - 2019. Penelitian ini merupakan penelitian deskriptif kuantitatif. Data yang digunakan dalam penelitian ini adalah perputaran modal kerja, perputaran kas, perputaran piutang, NPM, ROE dan ROA. Hasil penelitian menunjukkan bahwa modal kerja pada Koperasi Kredit Sami Jaya Kupang kurang efisien karena setiap tahun modal kerja tidak mencapai standar pengukuran menyebabkan profitabilitasnya pun menjadi tidak efisien.
\end{abstract}

Kata Kunci : Efisien, Modal Kerja, NPM, Profitabilitas, ROA, ROE

\begin{abstract}
This study aims to determine the working capital that has been managed efficiently, to determine the effect of working capital on profitability, and to determine the factors that affect the efficiency of working capital in the Sami Jaya Credit Cooperative in Kupang.The research period used is the period 2015 - 2019. This research is a quantitative descriptive study. The data used in this research are working capital turnover, cash turnover, accounts receivable turnover, NPM, ROE, and ROA.The results of this study indicate that the working capital of the Sami Jaya credit cooperative is less efficient because each year the working capital does not reach the standard measurement so that its profitability is also inefficient.
\end{abstract}

Keywords :Efficiency, Working Capital, NPM, Profitability, ROA, ROE.

Naskah diterima : 08-02-2021, Naskah dipublikasikan : 31-03-2021

\section{Introduction}

The development of the times and the increasingly advanced business world in Indonesia, has caused cooperatives to undergo evolution according to the era so that cooperative business forms become freer to develop, especially after the issuance of Presidential Instruction Number 18 of 1998 which aims to increase and encourage the spirit of self-reliance and initiative in cooperating among the community. Accompanied by the provision of convenience in establishing cooperatives in accordance with business feasibility and economic interests. A cooperative is a legal entity established by an individual or a cooperative legal entity, with the dividing of the assets of the members as capital to run a business that meets the common aspirations and needs in the economic, social and cultural fields in accordance with the values and principles of the cooperative. Cooperatives aim to improve the welfare of members in particular and society in general, as well as being an inseparable part of a democratic and just national economic order (Law of the Republic of Indonesia Number 17 of 2012 concerning Cooperatives, 2012). 
Credit cooperatives are business service institutions formed by a group of people who voluntarily save their money together so that a certain amount of capital is formed, which is then lent between them at a reasonable interest rate and in an easy way, whose management applies cooperative principles. The management of cooperatives must be based on cooperative principles, namely rationality, efficiency, effectiveness and productivity so that in the end the cooperative can prosper its members and get the maximum possible profit. The main activity of credit cooperatives is to provide deposit and loan services for members. So that in carrying out its main activities, it is very important for cooperatives to pay attention to the management of capital that operates in carrying out their activities so that working capital can be managed properly and efficiently to achieve maximum profit levels so that in the end they can prosper their members (Woeryanto, 2014).

In credit cooperatives, the working capital element plays an important role. If the cash turnover is slow compared to the standard set, the average cash balance will exceed demand. This indicates that there is idle cash because it is not used, so that it can reduce income. Apart from cash, it is also important to pay attention to the turnover of accounts receivable. The higher the turnover of accounts receivable, the faster the turnover, meaning that the shorter the time bound for capital is accounts receivable, the higher the turnover rate, which results in the more efficient working capital.

According to Riyanto (2001), the higher the turnover of accounts receivable, the faster the turnover, which means the shorter the time bound for capital is in receivables, the higher the turnover rate, the more efficient working capital. Because the higher the turnover rate, the faster the working capital in receivables will be recorded, so that the amount of working capital will be greater to finance receivables. The low level of accounts receivable turnover indicates that there is excess working capital embedded in receivables.

The role of capital in cooperative operations has a very important role because without sufficient capital, the cooperative's business will not run smoothly. Cooperatives with less healthy capital will work less smoothly and can even cause failure. On the other hand, a cooperative that works with a healthy capital will lead smooth business activities. In fact, it will generate trust from various parties, including members, entrepreneurs, creditors and banks (Ekawan, 2010).

The availability of working capital, which is quite important for the company in financing its operational activities. Therefore, companies must be able to use their capital effectively and efficiently. Regarding decisions in working capital management, the cooperative must be able to allocate financial resources efficiently and reduce the costs of using capital so as to increase profitability (SHU) in the future.

Profitability describes the level of the cooperative's ability to generate profits. The better the profitability, the better the level of profit the cooperative gets. Profitability is very important for cooperatives because they can find out the ability of cooperatives to manage their working capital efficiently.

Several studies have been conducted to see the efficiency of working capital on profitability. The results of Faurani \& Singangerda (2004) research reveal that working capital does not really have an effect on profitability at the Mandalika Cooperative. The same result is also shown by research conducted by Mukhotib (2008) which states that the efficiency level of using working capital is not effective at the SAE Pujon Cooperative. Meanwhile, Nurhidayah (2012) states that working capital turnover can be said to be efficient even though it is not efficient in terms of inventory turnover.

The Sami Jaya Kupang Credit Cooperative, carries out activities as an agency that collects and distributes funds to employees and the general public, but is inseparable from the problems of working capital management. Working capital in cooperatives is used to run all cooperative operations, so that the working capital owned is expected to be sufficient so that it can operate efficiently and be able to 
get maximum benefits for the cooperative. Therefore, cooperatives need to pay attention to the management of existing working capital so that they can operate efficiently to get maximum benefits.

Therefore, the Sami Jaya Credit Cooperative in carrying out its activities needs to pay attention to the capital used for operating activities so that the capital used can be managed efficiently in supporting each activity. With regard to decisions in terms of working capital management, the cooperative must be able to allocate financial resources efficiently and reduce the costs of using capital so that it will be able to increase profits or what is called the difference in operating results (SHU) in the future. So the efficiency that is meant is how the cooperative is able to generate profits (SHU) with the wealth or capital owned, both foreign capital and own capital and reduce the use costs as small as possible. The following is table 1 regarding the development of the Sami Jaya Credit Cooperative in Kupang :

Table 1. Data of Cash, Account Receivable and SHU Sami Jaya Credit Cooperative (In IDR)

\begin{tabular}{|c|c|c|c|c|c|c|c|c|c|}
\hline \multirow{2}{*}{ Year } & \multicolumn{3}{|c|}{ Cash } & \multicolumn{3}{c|}{ Account Recevaible } & \multicolumn{3}{c|}{ SHU } \\
\cline { 2 - 11 } & $\begin{array}{c}I D \\
\end{array}$ & $\%$ & & $I D R$ & $\%$ & & $I D R$ & $\%$ & \\
\hline 2015 & 4.565 .393 .170 & - & - & 20.201 .823 .992 & - & - & 42.612 .904 & - & - \\
\hline 2016 & 6.634 .039 .918 & 0,45 & Increase & 23.018 .931 .251 & 0,13 & Increase & 45.331 .354 & 0,06 & Increase \\
\hline 2017 & 4.014 .966 .805 & $(0,40)$ & Decrease & 26.628 .323 .685 & 0,15 & Increase & 54.116 .240 & $\begin{array}{c}0,2 \\
0\end{array}$ & $\begin{array}{l}\text { Increas } \\
e\end{array}$ \\
\hline 2018 & 4.447 .485 .428 & 0,10 & Increase & 29.038 .388 .116 & 0,10 & Increase & 55.301 .688 & 0,02 & Increase \\
\hline 2019 & 4.715 .723 .079 & 0,05 & Increase & 32.967 .974 .884 & 0,11 & Increase & 56.457 .032 & 0,02 & Increase \\
\hline
\end{tabular}

Sources : Sami Jaya Credit Cooperative, 2020

Table 1 shows that the working capital of the Sami Jaya Credit Cooperative in the form of cash has fluctuated and receivables continue to increase. The reason for the decline in cash is presumably because expenses are greater than income, and receivables continue to increase. Receivables have increased, presumably, the amount of funds, revolving around members and there are members who do not pay the loan according to time. On the other hand, the amount of SHU has increased every year. The amount of SHU or the profit earned is not a guarantee that the cooperative is working efficiently. This is due to working capital, namely cash has decreased, due to the large number of costs incurred in cooperative operations and others that have not been matched by an increase in current assets.

Based on this phenomenon, the purpose of this study is to determine the working capital owned by the Sami Jaya Cooperative has been managed efficiently so that it can provide impact on the profitability of the cooperative.

\section{Literature Review}

The Cooperative Law of the Republic of Indonesia No. 25 of 1992, states that what is meant by cooperatives is a business entity whose members are cooperative persons or legal entities which base their activities on the principles of cooperatives as well as as a people's economic movement based on the principle of kinship. According to Ekawarna (2010), defines cooperatives as economic organizations that seek to mobilize potential economic resources in order to advance the welfare of members. Because economic resources are limited and in developing a cooperative it must prioritize the interests of its members and face competition in the market, the cooperative must be able to work efficiently following the cooperative principles and economic principles. Therefore, the participation of members will greatly determine the success of the cooperative in helping achieve the economic goals of the members, in accordance with the cooperative's task to strengthen and develop the member economy.

Based on the description, it can be concluded that a cooperative is a business entity whose members are cooperative persons or legal entities, by basing the activities of cooperating in a family friendly 
manner by basing its activities on the principles of cooperatives as well as as a people's economic movement.

Working capital is capital that is used to finance the day-to-day operations of a company, especially those with a short term. Meanwhile, working capital management is a company investment management of assets if it is short. This means how to manage the company's investment and current assets (Kasmir, 2010). Mistakes or mistakes in working capital management will cause the company's financial condition to be bad so that the company's activities can be hampered or stopped altogether.

An indicator of good working capital management is the efficiency of working capital as seen from working capital turnover, starting from cash assets invested in the working capital component until it returns to cash (Husnan, 2013). The shorter the period the turnover, the faster the turnover, the higher the working capital turnover and the more efficient the company, namely the higher the profitability.

The definition of efficiency put forward by Anthony \& Govindarajan (2002)states that efficiency is the ratio of input to output or the number of outputs per unit of input. The same thing was stated by Horngren (2003) that efficiency is the optimum comparison between the input and expenditure. While Halim (2010) efficiency is the ratio between output and input or the number of outputs per unit compared to the input per unit. Efficiency measures can be developed by linking actual costs with predetermined standard costs. Based on the description above about the meaning of efficiency, it can be concluded that what is meant by efficiency is the ratio or comparison between output and input.

This working capital efficiency shows the management's achievement in managing company resources optimally. The more efficient the use of working capital, the better the company's management performance. Efficiency in working capital management is also very necessary to ensure long-term continuity or success and achieve the overall goals of the company which in this case increase wealth for the owner. Long-term success is greatly influenced by short-term success, because the efficiency of working capital management is important because it encourages companies to achieve long-term goals.

Profitability according to Riyanto (2001) is the company's ability to generate profits for a certain period. Weston \& Copeland (2001) suggest that profitability is the net result of a series of policy decisions. Meanwhile, Sartono (2011)defines profitability as the company's ability to earn profits in relation to its own assets and capital. If the company succeeds in increasing its profitability, it can be said that the company is able to manage its capital effectively and efficiently so that it can generate high profits. On the other hand, a cooperative that has low profitability indicates that the company is not able to manage the capital it owns properly, so that it is unable to generate high profits.

Aldrina's research result (2013) reveal that the working capital of the employee cooperative is unhealthy. This shows that the management of working capital in the cooperative is inefficient. Research conducted by Kumara \& Saputra (2014) reveals that current asset turnover has a negative and significant effect on profitability, which means that the higher the turnover of current assets, the lower the level of profitability of multi-business cooperatives. Fixed asset turnover has no effect on profitability, which means that changes in fixed asset turnover will not affect the level of profitability of a multi-business cooperative. Meanwhile, working capital turnover has a significant negative effect on profitability, which means that the higher turnover of upfront working capital, the lower the level of profitability of multi-business cooperatives.

The results of Febriyanti (2015)reveal that working capital efficiency is able to explain the dependent variable, namely profitability of 96.1 percent, while 3.9 percent is explained by other variables outside the variables studied. While Jauhari \& Ridwan (2017) conducted research on Sharia Cooperatives in Banda Aceh City, they found that the average efficiency of using working capital was higher when compared to the average effectiveness of working capital use at the Banda Aceh City 
Sharia Cooperative, which was 17.06 percent is the average efficiency, while the average effectiveness is 10.61 percent. This means that the average Banda Aceh City Sharia Cooperative tends to be efficient in using working capital to run its business rather than increasing its effectiveness.

\section{Research Method}

This study uses a quantitative descriptive approach that aims to explain the phenomena associated with the variables studied. The data used in this research is quantitative data, namely the financial statements of the Sami Jaya Credit Cooperative for the year 2014-2018. Data collection techniques by making observations, interviews and documentation studies. The data analysis technique in this study is to use comparative analysis during the observation period related to the efficiency of working capital and profitability of the Sami Jaya Kupang Credit Cooperative with measurement standards based on PMK No. 129 / Kep / M / KUKM / XI / 2002.

Working Capital Turnover

Working capital turnover is a financial ratio calculated by dividing income by the average working capital. The standard for measuring working capital turnover is based on the Decree of the State Minister for Cooperatives and Small and Medium Enterprises No. 129 / Kep / M / KUKM / XI / 2002 in table 2, as follows:

Table 2. Working Capital Turnover Measurement Standards

\begin{tabular}{ll}
\hline \multicolumn{1}{c}{ Standard } & \multicolumn{1}{c}{ Criteria } \\
\hline$>3$ times & Efficient \\
$3-2$ times & Simply Efficient \\
$1-0$ times & Less Efficient \\
$<0$ times & Not efficient \\
\hline Sources $:$ PMK No. $129 /$ Kep/M/KUKM/XI/2002
\end{tabular}

\section{Cash Turnover}

Cash turnover is the ability of cash to generate income so that it can be seen how many times cash has rotated in a certain period. The higher the cash turnover rate, the more efficient the level of cash use and vice versa. The standard for measuring cash turnover is based on the Decree of the State Minister for Cooperatives and Small and Medium Enterprises No. 129 / Kep / M / KUKM / XI/2002 in table 3, as follows:

Table 3. Cash Turnover Measurement Standard

\begin{tabular}{lc}
\hline \multicolumn{1}{c}{ Standars } & \multicolumn{1}{c}{ Criteria } \\
\hline 31 - >44 times & Efficient \\
$17-30$ times & Simply Efficient \\
$<17$ times & Less Efficient \\
\hline Sources $:$ PMK No. $129 /$ Kep/M/KUKM/XI/2002
\end{tabular}

Accounts Receivable Turnover

Accounts receivable turnover can be found by dividing the amount of revenue during a certain period by the average amount of accounts receivable. The higher the turnover, the faster the turnover. The standard of measuring receivables turnover based on the Cooperative regulations is shown in table 4, below:

Table 4. Accounts Receivable Turnover Measurement Standard

\begin{tabular}{cc}
\hline \multicolumn{1}{c}{ Standard } & \multicolumn{1}{c}{ Criteria } \\
\hline$>12$ times & Efficient \\
\hline
\end{tabular}




\begin{tabular}{lc}
\hline \multicolumn{1}{c}{ Standard } & \multicolumn{1}{c}{ Criteria } \\
\hline $10-<12$ times & Simply Efficient \\
$8-<10$ times & Less Efficient \\
$6-<8$ times & Not Efficient \\
$<6$ times & Very Inefficient \\
\hline Sources $:$ PMK No. $129 /$ Kep/M/KUKM/XI/2002
\end{tabular}

Net Profit Margin

Net profit margin is the ratio of total net income to total revenue. A high profit margin indicates the ability of the cooperative to generate high profits at a certain level of income and vice versa. The standard measurement of net profit margin is based on the Cooperative regulations in table 5, as follows:

Table 5. Net Profit Margin Standard

\begin{tabular}{ll}
\hline \multicolumn{1}{c}{ Standard } & \multicolumn{1}{c}{ Criteria } \\
\hline$>15 \%$ & Efficient \\
$10 \%-<15 \%$ & Simply Efficient \\
$5 \%-<10 \%$ & Less Efficient \\
$1 \%-<5 \%$ & Not Efficient \\
$<1 \%$ & Very Inefficient \\
\hline Sources: PMK No. $129 /$ Kep/M/KUKM/XI/2002
\end{tabular}

Return On Equity

Return on equity is the amount of net profit on equity and is expressed as a percentage. ROE is used to measure the ability of cooperatives to generate profits. The standard measurement of return on equity is shown in table 6, below:

Table 6. Return On Equity Standard

\begin{tabular}{ll}
\hline Standard & Criteria \\
\hline$>21 \%$ & Efficient \\
$15 \%-<21 \%$ & Simply Efficient \\
$9 \%-<15 \%$ & Less Efficient \\
$3 \%-<9 \%$ & Not Efficient \\
$<3 \%$ & Very Inefficient \\
\hline Sources : PMK No. $129 /$ Kep/M/KUKM/XI/2002
\end{tabular}

Return On Assets

Return on assets is a comparison between profit after tax and total assets. The higher the ROA, the greater the profit the cooperative gets and the better the position of the cooperative in terms of asset use. The standard measurement of return on assets based on cooperative regulations is shown in table 7, as follows:

Table 7. Net Profit Margin Standard

\begin{tabular}{ll}
\hline Standard & Criteria \\
\hline$>10 \%$ & Efficient \\
$15 \%-<21 \%$ & Simply Efficient \\
$9 \%-<15 \%$ & Less Efficient \\
$3 \%-<9 \%$ & Not Efficient \\
$<3 \%$ & Very Inefficient \\
\hline Sources : PMK No. $129 /$ Kep/M/KUKM/XI/2002
\end{tabular}




\section{Result and Discussion}

This type of research is a case study research. A case study is an approach to studying, explaining or interpreting a case in its natural context without any outside intervention. The research approach used by researchers in this study is a quantitative descriptive approach. The results of the analysis of working capital efficiency on profitability of the Sami Jaya Credit Cooperative in Kupang City can be seen in table 8 below:

Table 8. Efficiency of Working Capital on Profitability

\begin{tabular}{|c|c|c|c|c|c|}
\hline No & Component & Year & Result & Standart & Criteria \\
\hline \multirow[t]{4}{*}{1} & Working Capital & $2015 / 2016$ & 0,174 & $>3$ & Less Efficient \\
\hline & Turnover & $2016 / 2017$ & 0,195 & $>3$ & Less Efficient \\
\hline & & $2017 / 2018$ & 0,179 & $>3$ & Less Efficient \\
\hline & & $2018 / 2019$ & 0,184 & $>3$ & Less Efficient \\
\hline \multirow[t]{4}{*}{2} & Cash Turnover & $2015 / 2016$ & 28 & $31->44$ & Quite Efficient \\
\hline & & $2016 / 2017$ & 19 & $31->44$ & Quite Efficient \\
\hline & & $2017 / 2018$ & 31 & $31->44$ & Efficient \\
\hline & & $2018 / 2019$ & 200 & $31->44$ & Efficient \\
\hline \multirow[t]{4}{*}{3} & Receivable & $2015 / 2016$ & 0,161 & $>12$ & Very Inefficient \\
\hline & turnover & $2016 / 2017$ & 0,172 & $>12$ & Very Inefficient \\
\hline & & $2017 / 2018$ & 0,152 & $>12$ & Very Inefficient \\
\hline & & $2018 / 2019$ & 0,153 & $>12$ & Very Inefficient \\
\hline \multirow[t]{5}{*}{4} & Net Profit Margin & 2015 & $\begin{array}{l}1,23 \\
\text { percent }\end{array}$ & $>15$ percent & Inefficient \\
\hline & & 2016 & $\begin{array}{l}1,29 \\
\text { percent }\end{array}$ & $>15$ percent & Inefficient \\
\hline & & 2017 & $\begin{array}{l}1,26 \\
\text { percent }\end{array}$ & $>15$ percent & Inefficient \\
\hline & & 2018 & $\begin{array}{l}1,39 \\
\text { percent }\end{array}$ & $>15$ percent & Inefficient \\
\hline & & 2019 & $\begin{array}{l}1,18 \\
\text { percent }\end{array}$ & $>15$ percent & Inefficient \\
\hline \multirow[t]{5}{*}{5} & Return On Equity & 2015 & $\begin{array}{l}2,22 \\
\text { percent }\end{array}$ & $>21$ percent & Very Inefficient \\
\hline & & 2016 & $\begin{array}{l}2,16 \\
\text { percent }\end{array}$ & $>21$ percent & Very Inefficient \\
\hline & & 2017 & $\begin{array}{l}2,37 \\
\text { percent }\end{array}$ & $>21$ percent & Very Inefficient \\
\hline & & 2018 & $\begin{array}{l}2,24 \\
\text { percent }\end{array}$ & $>21$ percent & Very Inefficient \\
\hline & & 2019 & $\begin{array}{l}2,09 \\
\text { percent }\end{array}$ & $>21$ percent & Very Inefficient \\
\hline \multirow[t]{5}{*}{6} & Return On Asset & 2015 & $\begin{array}{l}1,44 \\
\text { percent }\end{array}$ & $>10$ percent & Inefficient \\
\hline & & 2016 & $\begin{array}{l}1,31 \\
\text { percent }\end{array}$ & $>10$ percent & Inefficient \\
\hline & & 2017 & $\begin{array}{l}1,52 \\
\text { percent }\end{array}$ & $>10$ percent & Inefficient \\
\hline & & 2018 & $\begin{array}{l}1,44 \\
\text { percent }\end{array}$ & $>10$ percent & Inefficient \\
\hline & & 2019 & $\begin{array}{l}1,33 \\
\text { percent }\end{array}$ & $>10$ percent & Inefficient \\
\hline
\end{tabular}


Sources : Data Analysis, 2020

Working capital turnover shows the relationship between the amount of income in one period with the existing working capital. The higher the working capital turnover, the more efficient. Table 8 shows the efficiency of working capital the profitability of the Sami Jaya credit cooperative. The turnover of working capital achieved by the Sami Jaya Credit Cooperative in Kupang in 2015/2016 was 0.174 times, this means that first time the rotating working capital can generate 0.174 times the total income. In 2016/2017 working capital rotates 0.195 times, this means that first time rotating working capital can generate 0.195 times total income. In 2017/2018 the turnover of working capital was 0.179 times, this means that first time the rotating working capital can generate 0.179 times the total income. In 2018/2019 working capital rotates at 0.184 times, this means that first time rotating working capital can result in 0.184 times the total achievement. If the rate of working capital turnover compares to the predetermined measurement standards, the turnover of working capital at the Sami Jaya Credit Cooperative from 2015/20 16 to 2018/2019 is included in the inefficient criteria.

These results explain that the level of working capital turnover obtained by the Sami Jaya Credit Cooperative is low. The low rate of working capital turnover indicates an excess of working capital which results in excess funds invested. This indicates that the application of working capital is not going well. Because cooperatives need to pay attention to policies related to working capital management, namely policies in determining the amount of funds to be invested according to business needs.

The cash turnover generated by the Sami Jaya Credit Cooperative in 2015/2016 was 28 times, which means that first time the average cash spin can generate 28 times the total income. In 2016/2017 cash turnover was 19 times, this means that first times average cash turnover can generate 19 times total revenue. In 2017/2018 cash turnover was 31 times, this means that first time the average cash turnover can generate 31 times total revenue. While in 2018/2019 cash turnover was 200 times, this means that first time the average cash turnover can generate 200 times total revenue. If these figures are compared with the measurement standard, the cash turnover ratio in 2015/2016 and 2016/2017 is included in the Criteria is quite efficient, while in 2017/2018 and 2018/2019 are included in the criteria for efficiency.

The high level of cash turnover indicates that the cooperative is efficient in using cash. The higher the cash turnover rate, the faster cash will enter the cooperative. So that the incoming cash can be used again to finance the operational activities of the cooperative, which the end the profit received by the cooperative can increase.

Receivables turnover achieved by Sami Jaya Credit Cooperative in 2015/2016 was 0.161, this means that first time the average rotating receivables can result in 0.161 times the achievement. In 2016/2017 the accounts receivable turnover was 0.172, this means that first time the average rotating accounts receivable can produce 0.172 times of income. In 2017/2018, the turnover of accounts receivable was 0.152 times, this means that first time the average rotating accounts receivable yields 0.152 times the total revenue. And in 2018/2019 the turnover of accounts receivable was 0.153, which means that first time the average rotating accounts receivable can generate 0.153 times the income. When the accounts receivable turnover compares to the predetermined measurement standards, the receivables turnover in 2015/2016 to 2018/2019 is very inefficient. This turnover is said to be very inefficient because each year the receivables are not collected more than 12 times to generate income. Accounts receivable turnover rate is very inefficient because the members pay their obligations not on time.

Table 8 also explains that the profit margin achieved by the Sami Jaya Credit Cooperative in 2015 was 1.23 percent, which means that every IDR 1 of revenue generates SHU of IDR 0.0123. In 2016 the NPM was 1.29 percent, which means that every IDR 1, - of income generates a SHU of IDR 0.0129. In 2017 the NPM was 1.26 percent, which means that every IDR.1, - of income generates SHU of IDR. 
0.0126. In 2018 the NPM was 1.30 percent, which means that every IDR 1 of revenue generates SHU of IDR 0.0130. And in 2019 the NPM income was 1.18 percent, which means that every IDR.1, - income generates SHU of IDR. 0.0118. If these results are compared with the expenditure standards that have been set, the NPM ratio at the Sami Jaya Credit Cooperative from 2015 - 2019 is included in the inefficient criteria.

The Return on Equity achieved by the Sami Jaya Credit Cooperative in 2015 was 2.22 percent, which means that every IDR 1, - own capital generates SHU of IDR 0.0222. In 2016 ROE was 2.16 percent, which means that every IDR 1, - own capital generates a SHU of IDR 0.0216. In 2017, ROE was 2.37 percent, which means that every IDR 1, - own capital generates a SHU of IDR 0.0237. In 2018, ROE was 2.24 percent, which means that every IDR 1, - your own capital generates a SHU of IDR 0.0224. And in 2019 ROE was 2.19 percent, which means that every IDR 1, - own capital generates a SHU of IDR 0.0209. If these figures are compared with the measurement standard, the Return on Equity from 2015 - 2019 is considered very inefficient.

The Return on Asset (ROA) obtained by the Sami Jaya Credit Union in 2015 was 1.44 percent, which means that every IDR 1.- total assets generate SHU of IDR 0.0144. In 2016, ROA was 1.31 percent, which means that every IDR 1, - total assets resulted in the SHU of IDR 0.0131. In 2017, ROA was 1.52 percent, which means that every IDR 1. - total assets resulted in the SHU of IDR 0.0152. In 2018, ROA was 1.44 percent, which means that for every IDR 1, total assets generate SHU of IDR 0.0144 . And in 2019 the ROA is 1.33 percent, which means that every IDR 1, - total assets generate a SHU of IDR 0.0133. If the ROA results are compared with the standard measurement, the Return on Asset of the Sami Jaya Credit Cooperative is included in the inefficient criteria. The results of this study are the same research conducted by Aldrina (2013) which states that the working capital used is categorized as unhealthy.

\section{Conclusion}

Based on the results of the analysis of working capital at the Sami Jaya Credit Cooperative, it can be said that it is inefficient. Because almost all of the turnover did not reach the predetermined target.

Based on the results of the analysis of working capital turnover at the Sumi Jaya Credit Cooperative from 2015/2016 to 2018/2019 shows very small results from predetermined standards. So that working capital of the Sami Jaya Credit Cooperative has an effect on profitability. Because the smaller the working capital turnover, the more it will affect profitability. This can be seen from the profitability ratio, which uses three ratios, namely NPM. ROE and ROA are not efficient.

Based on the results of the analysis, the Sami Jaya Cooperative accounts receivable turnover is low. This is due to the high outstanding outstanding receivables so that the realization value is smaller The analysis shows that the factors that affect the efficiency of working capital at the Sami Jaya Credit Cooperative are cash turnover.

\section{Suggestion}

For the Sami Jaya cooperative, it is necessary to improve the efficiency of working capital, especially working capital turnover and accounts receivable turnover. Sufficient working capital management is necessary so that various cooperative activities can be carried out smoothly. In addition, it is hoped that the Sami Jaya Cooperative can continue to improve cash management so that it can be more efficient in utilizing money management in the coming period.

For further research it is recommended to extend the observation period and add other financial ratio indicators that have not been used in this study. 


\section{REFERENSI}

Aldrina, C. R. (2013). PENGARUH EFISIENSI MODAL KERJA TERHADAP PROFITABILITAS : Studi pada Koperasi Pegawai Dinas Koperasi 12 Juli. Universitas Pendidikan Indonesia.

Anthony, Robert N, G. (2002). Management Control System, Buku 1. Salemba Empat.

Apsari. E, S. (1987). Proses Penyusunan Laporan Keuangan Untuk Koperasi Simpan Pinjam. Liberty.

Bambang Riyanto. (2001). Dasar-Dasar Pembelanjaan Perusahaan. Edisi keempat. Cetakan Ketujuh. Yogyakarta: BPFE Yogyakarta

Ekawarna. (2010). Manajemen Keuangan dan Koperasi. Gaung Persada Press.

Faurani, A \& S Singangerda (2004). Analisis Pengaruh Modal Kerja Terhadap Profitabilitas Dan Rentabilitas Pada Koperasi Dharma Wanita "Mandalika" Mataram Nusa Tenggara Barat. Jurnal manajemen keuangan 10 (2), 54-64.

Febriyanti, N. A. (2015). Analisis pengaruh efisiensi modal kerja, likuiditas, dan solvabilitas terhadap profitabilitas periode 2005-2014: Studi pada Koperasi Potre Koning Sumenep. Universitas Islam Negeri Maulana Malik Ibrahim. http://etheses.uin-malang.ac.id/865/.

Halim, Abdul. (2010). Manajemen Keuangan. BPFE Yogyakarta

Horngren, Charles. (2003). Akuntansi Biaya Penekanan Manajerial Jilid Satu. PT. Indeks Kelompok Gramedia. Jakarta.

Husnan, S. (2013). MANAJEMEN KEUANGAN Teori dan Penerapan (4th ed.). BPFE Fakultas Ekonomi UGM.

Jauhari, R., \& Ridwan. (2017). EFISIENSI DAN EFEKTIVITAS PENGGUNAAN MODAL KERJA PADA KOPERASI SYARIAH DI KOTA BANDA ACEH TAHUN 2011-2015. Jurnal Ilmiah Mahasiswa Ekonomi Akuntansi (JIMEKA), 2(3), 168-179.

Kasmir. (2010). Pengantar Manajemen Keuangan. Kencana Prenada Media Group.

Kumara, D. P., \& Saputra, I. D. G. D. (2014). PENGARUH EFISIENSI MODAL KERJA PADA PROFITABILITAS KOPERASI SERBA USAHA. E-Jurnal Akuntansi Universitas Udayana, 9(2).

Mukhotib. (2008). Efisiensi Penggunaan Modal Kerja Dalam Meningkatkan Profitabilitas Pada Koperasi SAE Pujon. Skripsi,FE UIN Malang.

Nurhidayah, Ema. 2012. "Analisis Efisiensi Modal Kerja untuk Meningkatkan Profitabilitas (Studi Kasus Pada Distributor Pupuk Sugih Waras Di Ponorogo)".Skripsi. Jurusan Akuntansi Univ. Muhammadiyah Ponorogo

Riyanto, B. (2001). Dasar-dasar Pembelanjaan Perusahaan. BPFE Fakultas Ekonomi UGM.

Undang-Undang Republik Indonesia Nomor 17 Tahun 2012 Tentang Perkoperasian, Pub. L. No. 17, Perkoperasian 1 (2012).

Weston, J. Fred dan Copeland, T. E. (2001). Manajemen Keuangan Jilid I. Binarupa Aksara.

Woeryanto, H. (2004). Koperasi Kredit Untuk Anda. Penerbit Bekatiga Indonesia Jakarta. 